\title{
TAXONOMIC RELATIONSHIPS OF SOME SARRACENIA SPP. (Sarraceniaceae) ARE not Deducible based on Palynology
}

MichaEL S. BodRI • Department of Biology $\bullet$ School of Science \& Health Professions $\bullet$ North Georgia College \& State University • Dahlonega, GA $30597 \cdot$ USA • msbodri@ngcsu.edu RoberT SinN - Department of Math \& Computer Science - School of Science \& Health Professions • North Georgia College \& State University • Dahlonega, GA $30597 \bullet$ USA

Keywords: taxonomy: pollen, Sarracenia.

\begin{abstract}
Pollen morphometrics for Sarracenia alata, S. flava, S. minor, S. purpurea and S. rubra were determined in an effort to utilize polar and equatorial dimensions to help determine species relationships. Although Sarracenia flava was found to be distinct from the other species, which in themselves form a distinct group, this study found that pollen morphometrics do not allow greater distinction between species. Therefore, pollen measurements are not valid in determining phylogenetic relationships for the genus.
\end{abstract}

\section{Introduction}

Phylogenetic relationships of the carnivorous plant family Sarraceniaceae have been examined based upon floral morphology and embryology (DeBuhr 1975), palynology (Thanikaimoni \& Vasanthy 1972), and more recently upon nuclear ribosomal DNA (Bayer et al. 1996). A sister group relationship of Roridula and Sarraceniaceae is supported by both morphological data (Conran \& Dowd 1993) as well as genetic analysis (Bayer et al. 1996; Chase et al. 1993).

Within the family Sarraceniaceae, the genus Sarracenia comprises approximately eight recognized species (S. alata, S. flava, S. leucophylla, S. minor, S. oreophila, S. psittacina, S. purpurea, $S$. rubra) and two to three subspecies ( $S$. purpurea subsp. venosa var. burkii=S. rosea, $S$. rubra subsp. alabamensis, $S$. rubra subsp. jonesii) considered by some to deserve species ranking. The extent to which the species are able to hybridize creates problems in the taxonomy at the species level. Because all the species can hybridize with each other and produce fertile offspring, taxonomists are unable to use degrees of infertility as a means for indicating degrees of relationship. Adding more complexity to the resolution of taxonomic relationships, different species clades are constructed depending upon whether plastid DNA (Freudenstein \& Case 2002) or nuclear DNA (ISSR, i.e., inter-simple sequence repeat, amplification reactions) is utilized (Freudenstein et al. 2004). Interspecific hybridization, particularly introgression (Bayer et al. 1996), small population sizes prone to inbreeding and genetic drift (Wang et al. 2004), and a relatively genetically depauperate genus due to discontinuous distributions (Godt \& Hamrick 1996) have all been postulated as explanations for the difficulty in deducing species relationships based upon DNA evidence.

Reliance upon plant life history, specifically seed traits, suggests characters such as germination and seed size are related more to geography than to phylogeny, although intraspecific groupings of populations of S. purpurea based on isozyme analysis (Godt \& Hamrick 1996) are supported by germination studies (Ellison 2001). Morphology of leaves and flowers, the principal basis for current taxonomy, is also disputed as the best means for species identification and taxonomic relationships (Case \& Case 1976; McDaniel 1971; Schnell \& Krider 1976; Sheridan 1991). 
Even though relied upon as the current means for species identification and taxonomy, the morphology of pitcher plant leaves and flowers has resulted in differing perspectives as to specific and infraspecific delineations and classifications within the genus (Case \& Case 1976; McDaniel 1971; Schnell \& Krider 1976; Sheridan 1991). For example, S. rubra subsp. jonesii has been variously classified as a distinct species or as a form or regional variant of S. rubra, attesting to the variability of leaf and flower morphology.

Established early in meiosis, species-specific pollen wall patterns can be used for taxonomic classification (Edlund et al. 2004). Pollen development in Sarracenia was studied as early as 1908 (Nichols 1908). Thanikaimoni \& Vasanthy (1972) utilized palynology to distinguish between the genera in Sarraceniaceae and formulate a tentative phylogeny with other families but no attempt was made to identify species relationships within the family. It has been recognized that female reproductive tissues such as the stigma are able to discriminate between pollen grains, recognizing pollen from the same species while rejecting pollen from unrelated species (or from the same plant in self-incompatible species) (Edlund et al. 2004). Because of this, the present study was undertaken in the hope that morphometrics (the extraction of measurements from shapes) of pollen, can be utilized to help ascertain species relationships within the genus Sarracenia.

\section{Materials and Methods}

Mature pollen was collected from blooming plants maintained in one of the author's bog garden (MSB). Plants originated from either pure stands collected under permit ( $S$. alata in LA, $S$. minor in GA, and $S$. purpurea in NJ) or from a commercial nursery specializing in carnivorous plants (Lee's Botanical Gardens, LaBelle, FL, S. flava, S. rubra). Clean tooth picks were used to scrape pollen from the umbraculum of flowers that had been enclosed by fine mesh bags to prevent entry by insect pollinators. Pollen was then transferred onto a thin film of silicon grease smeared on a glass slide. Pollen slides were flooded with Calberla stain $(5.0 \mathrm{ml}$ glycerol, $10 \mathrm{ml}$ 95\% ethanol, $15 \mathrm{ml}$ distilled water, 2 drops of saturated, aqueous solution of basic fuchsin) followed by application of a cover slip prior to microscopic examination. This stain rehydrates pollen grains and reacts with sporopollenin to turn grains red for easier viewing under the microscope. Pollen was visualized using an Olympus BX60 fluorescent microscope equipped for differential interference contrast (DIC) microscopy. Images were captured with The Spot ${ }^{\mathrm{TM}}$ Advanced CCD (Diagnostic Instruments, Inc, Sterling Heights, MI) and processed using The Spot Advanced (Version 4.0.2.0) software calibrated to the objective lenses. Pollen was measured in polar and equatorial surface view and data then analyzed by ANOVA (SPSS, SPSS, Inc., Chicago, IL).

\section{Results}

Pollen morphometrics based on polar and equatorial views (see Figure 1) of the species of Sarracenia studied are presented in Table 1 along with comparison data on size ranges reported previously (Thanikaimoni \& Vasanthy 1972). Species examined include S. alata, S. flava, S. minor, S. purpurea and $S$. rubra. Based on morphometrics, S. flava is shown to be distinct from the other species which form a separate group. Normality and independence were verified prior to statistical analysis. Histo-gram and box-plots show the

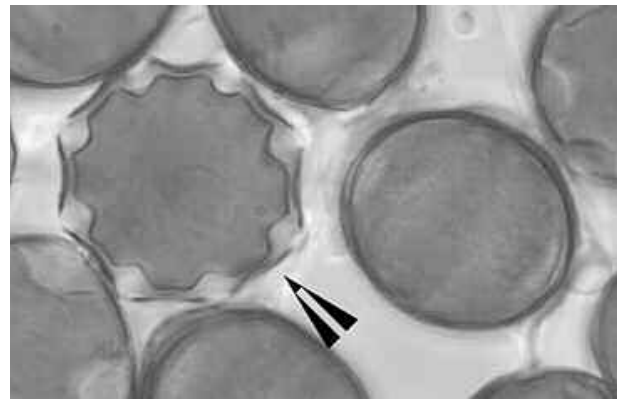

Figure 1: Representative photomicrograph of the pollen of Sarracenia alata following treatment with Calberla stain (100x). The arrow head depicts a pollen grain in polar view while the grain to its right is aligned in equatorial view. 
dependent variables to be roughly normally distributed in all groups. Independence is verified in the methodology and is not a concern for this type of research. A possible problem arises with the homogeneity of variances assumption due to the fact that the sample sizes are distinctly unequal for both the polar and equatorial measurement dependent variables. A Levene's test for equality of variances indicated no reason to believe this statistical analysis suffered from a violation of this assumption (see Table 2).

Post hoc analysis of power (sensitivity) indicated that the power of the ANOVA tests to pick up true differences between means was $80 \%$ for equatorial measurements and $99 \%$ for polar measurements.

\section{Discussion}

The pollen morphology of the Sarracenia species examined is 6-9 colporate in agreement with Thanikaimoni \& Vasanthy (1972). Polar and equatorial measurements in this study are all within the range previously reported by them following acetolysis treatment of the pollen (Thanikaimoni \& Vasanthy 1972). Pollen treated with Wodehouse solution tends to be smaller than pollen treated by acetolysis and our data, for polar measurements, supports this observation. In equatorial view, the measurements obtained in this study fall within the Thanikaimoni \& Vasanthy (1972) ranges for Wodehouse solution-treated pollen. Acetolysis treatment usually damages the aperture membrane but the structure of the exine at the non-apertural region appears clear. Wodehouse solution preserves the aperture membrane, symmetry and shape of the pollen grain. The exine appears superficially similar in all species examined and was not utilized in an attempt to determine species relationships.

Violations of the normality assumption in ANOVA do not adversely affect the actual level of significance observed. All the samples are roughly normal and the samples were large enough to ensure accurate determination of significance. Due to the unequal group sizes in this study, the Levene's test was utilized to verify the homogeneity of variances assumption because of its robustness and lack of sensitivity to non-normality of the sample data. The data sets met all the requirements for using ANOVA.

\begin{tabular}{|c|c|c|c|c|c|}
\hline & S. alata & S. flava & S. minor & S. purpurea & S. rubra \\
\hline $\begin{array}{l}\text { Polar } \\
(\text { mean } \pm \text { s.d. })\end{array}$ & $\begin{array}{l}23.59^{\mathrm{a}} \pm 0.72 \\
(\mathrm{n}=27)\end{array}$ & $\begin{array}{l}25.68^{b} \pm 1.12 \\
(n=31)\end{array}$ & $\begin{array}{l}23.40^{\mathrm{a}} \pm 1.02 \\
(\mathrm{n}=18)\end{array}$ & $\begin{array}{l}23.51^{\mathrm{a}} \pm 1.22 \\
(\mathrm{n}=38)\end{array}$ & $\begin{array}{l}24.08^{\mathrm{a}} \pm 0.95 \\
(\mathrm{n}=19)\end{array}$ \\
\hline $\begin{array}{l}\text { Polar } \\
\text { (range) }\end{array}$ & $22.6-25.7$ & $23.6-29.1$ & $22.3-26.4$ & $21.4-26.5$ & $23.4-27.3$ \\
\hline $\begin{array}{l}\text { Equatorial } \\
\text { (mean } \pm \text { s.d.) }\end{array}$ & $\begin{array}{l}18.46^{\mathrm{a}} \pm 0.60 \\
(\mathrm{n}=18)\end{array}$ & $\begin{array}{l}18.98^{b} \pm 0.76 \\
(n=14)\end{array}$ & $\begin{array}{l}18.98^{\mathrm{a}} \pm 0.99 \\
(\mathrm{n}=15)\end{array}$ & $\begin{array}{l}18.43^{\mathrm{a}} \pm 0.76 \\
(\mathrm{n}=19)\end{array}$ & $\begin{array}{l}18.43^{\mathrm{a}} \pm 0.76 \\
(\mathrm{n}=19)\end{array}$ \\
\hline $\begin{array}{l}\text { Equatorial } \\
\text { (range) }\end{array}$ & $18.2-20.4$ & $18.0-21.0$ & $18.2-21.2$ & $17.5-20.2$ & $17.6-20.5$ \\
\hline $\begin{array}{l}\text { Polar } \\
\text { (range) }\end{array}$ & $16-20$ & $13-24$ & $16-22$ & 16-19 & $17-22$ \\
\hline $\begin{array}{l}\text { Equatorial } \\
\text { (range) }\end{array}$ & $17-23$ & $15-23$ & $14-20$ & $19-22$ & $13-21$ \\
\hline $\begin{array}{l}\text { Polar } \\
\text { (range) }\end{array}$ & $19-27$ & $20-27$ & $16-24$ & $18-27$ & $18-25$ \\
\hline $\begin{array}{l}\text { Equatorial }^{\mathrm{d}} \\
\text { (range) }\end{array}$ & $15-26$ & $15-25$ & $14-21$ & $16-29$ & $16-24$ \\
\hline \multicolumn{6}{|c|}{ 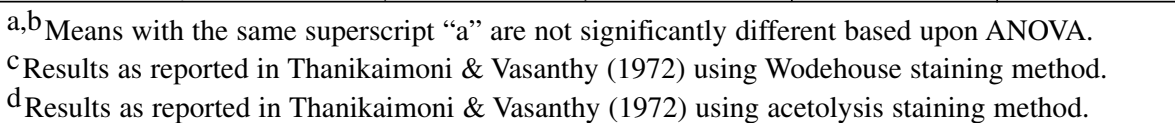 } \\
\hline
\end{tabular}

Table 1: Morphometrics of Sarracenia pollen grains $(\mu)$. 


\begin{tabular}{|l|c|c|c|c|}
\hline & F & Df1 & Df2 & Sig. \\
\hline Equatorial & 1.612 & 4 & 72 & 0.180 \\
Polar & 1.607 & 4 & 72 & 0.182 \\
\hline aDesign: Intercept + Grp & \\
\hline
\end{tabular}

Table 2: Levene's test of equality of error variancesa. This tests the null hypothesis that the error variance of the dependent variable is equal across groups.

Post hoc estimates of power provide legitimate information in exploratory settings where an a priori estimate is not feasible. Power is strongly influenced by the level of significance, sample size and effect size. No universal rule for adequate power is available, but power of $80 \%$ or greater is sufficient for most research settings.

For analysis of equatorial values, with an average group size of 15.4, power of approximately $80 \%$ was determined. For the polar data, with an average group size of 26.6 , power of $99 \%$ was determined, which is extremely strong. These post hoc estimates indicate that the power of the ANOVA tests to pick up true differences was sufficient for the equatorial data and immense for the polar data.

The separation of $S$. flava from the other species examined in this study is inconsistent with the results from other investigations. Interestingly, similarly to our own result, Bayer et al. (1996) had one species of Sarracenia ( $S$. alata) as a sister group to a clade containing all the other species his group examined based on rbcL and ITS sequences. Sarracenia flava was found to be aligned with $S$. alata, S. leucophylla, S. purpurea, S. psittacina, and S. rubra by Freudenstein \& Case (2002) based upon plastid DNA analysis, and in a later study utilizing nuclear DNA with just $S$. oreophila (Freudenstein et al. 2004). It was hoped these inconsistencies in species relationships could be addressed by utilizing pollen measurements, but we were unable to provide a precise means of distinguishing between all the species examined in this study by comparison of polar and equatorial dimensions. Unfortunately, the lack of resolution of relationships among Sarracenia species based upon pollen morphometrics excludes this technique as a way of elucidating their confounding taxonomy.

\section{References}

Bayer, R.J., Hufford, L., and Soltis, D.E. 1996. Phylogenetic relationships in Sarraceniaceae based on rbcL and ITS sequences. Systematic Botany. 21: 121-134.

Case, F.W. and Case, R.B. 1976. The Sarracenia rubra complex. Rhodora. 78: 270-325.

Chase, M.W., Soltis, D.E., Olmstead, R.G., Morgan, D., Les, D.H., Mishler, B.D., Duvall, M.R., Price, R.A., Hills, H.G., Qui, Y.-L., Kron, K.A., Rettig, J.H., Conti, E., Palmer, J.D., Manhart, J.R., Sytsma, K.J., Michaels, H.J., Kress, W.J., Karol, K.G., Clark, W.D., Hedren, M., Gaut, B.S., Jansen, R.K., Kim, K.-J., Wimpee, C.F., Smith, J.F., Furnier, G.R., Strauss, S.H., Xiang, Q.-Y., Plunkett, G.M., Soltis, P.S., Swensen, S.M., Williams, S.E., Gadek, P.A., Quinn, C.J., Eguiarte, L.E., Goldenberg, E., Learn Jr., G.H., Graham, S.W., Barrett, S.C.H., Dayanandan, S., and Albert, V.A. 1993. Phylogenetics of seed plants: An analysis of nucleotide sequences from the plastid gene rbcL. Annals of the Missouri Botanical Garden. 80: 528-580.

Conran, J.G. and Dowd, J.M. 1993. The phylogenetic relationships of Byblis and Roridula (Byblidaceae-Roridulaceae) inferred from partial 18S ribosomal RNA sequences. Plant Systematics and Evolution. 188: 73-86.

DeBuhr, L.E. 1975. Phylogenetic relationships of the Sarraceniaceae. Taxon. 24: 297-306.

Edlund, A.F., Swanson, R., and Preuss, D. 2004. Pollen and stigma structure and function: The role of diversity in pollination. The Plant Cell. 16: S84-S97.

Ellison, A.M. 2001. Interspecific and intraspecific variation in seed size and germination requirements of Sarracenia (Sarraceniaceae). Am. J. of Botany 88: 429-437. 
Freudenstein, J.V. and Case, F.W. 2002. Relationships among pitcher plant species (Sarracenia) based on plastid DNA sequence analysis. Bot. Soc. of Am./American Society of Plant Taxonomy meetings (Botany 2002), Madison, WI, 4-7 August.

Freudenstein, J.V., Chaudhuri, A., and Case, F.W. 2004. Relationships among and delimitation of Sarracenia species: A nuclear DNA perspective. Bot. Soc. of Am. meeting (Botany 2004), Snowbird, UT, 1-4 August.

Godt, M.J.W. and Hamrick, J.L. 1996. Genetic structure of two endangered pitcher plants, Sarracenia jonesii and Sarracenia oreophila (Sarraceniaceae). Am. J. of Botany. 83: 1016-1023.

McDaniel, S. 1971. The genus Sarracenia (Sarraceniaceae). Bull. of the Tall Timbers Res. Station. 9: 1-36.

Nichols, M.L. 1908. The development of the pollen of Sarracenia. Bot. Gazette. 45: 31-37.

Schnell, D.E. and Krider, D.W. 1976. Cluster analysis of the genus Sarracenia L. in the southeastern United States. Castanea. 62: 60-62.

Sheridan, P.M. 1991. What is the identity of the west gulf coast pitcher plant, Sarracenia alata Wood? Carniv. Pl. Newslett. 20: 102-110.

Thanikaimoni, G. and Vasanthy, G. 1972. Sarraceniaceae: Palynology and systematics. Pollen et spores. 14: 143-155.

Wang, Z-F., Hamrick, J.L., and Godt, M.J.W. 2004. High genetic diversity in Sarracenia leucophylla (Sarraceniaceae), a carnivorous wetland herb. J. of Heredity. 95: 234-243
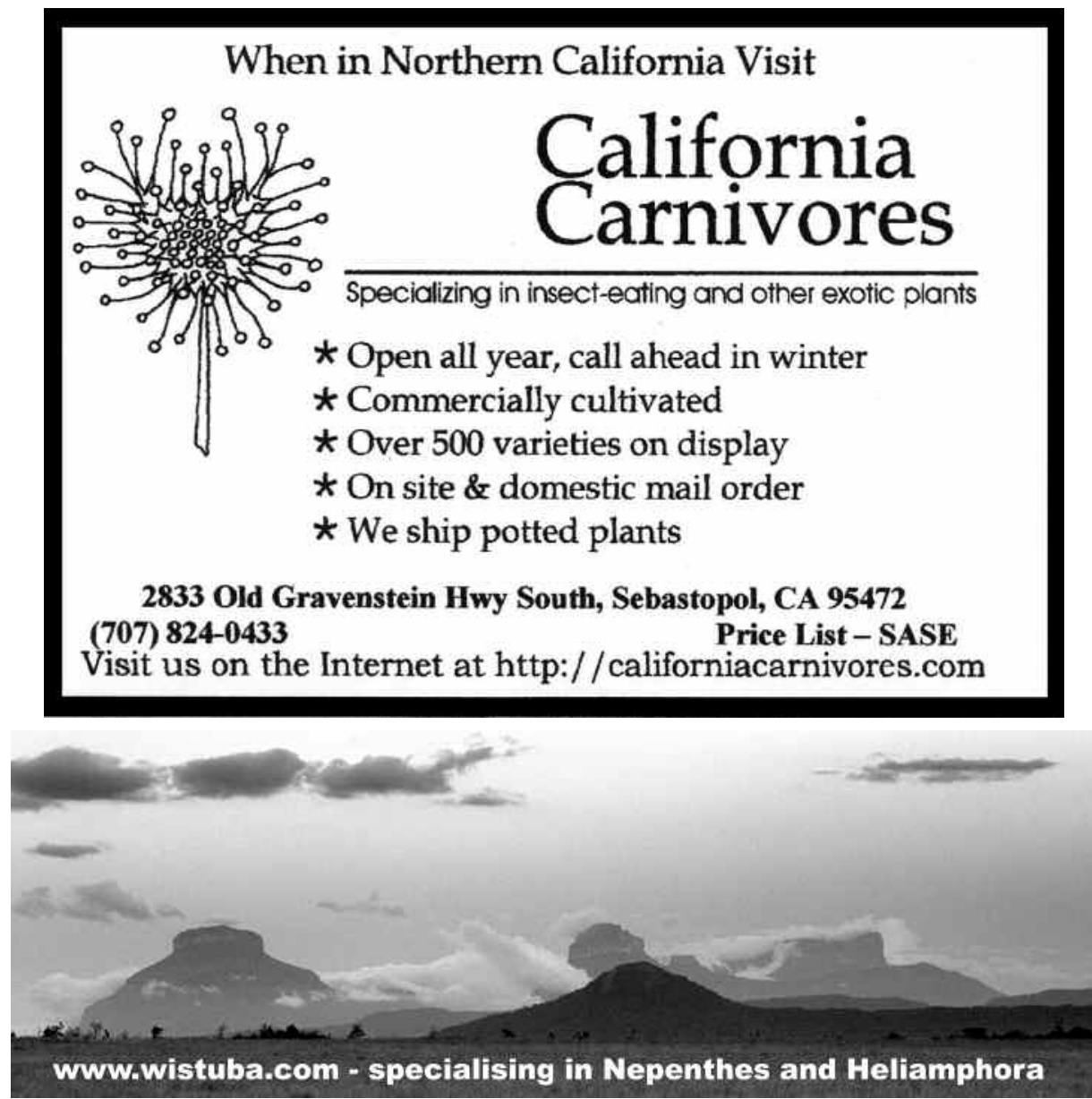